$\begin{array}{ccc}\text { Tersedia online di: http://ejournal-balitbang.kkp.go.id/index.php/jppi } & \text { JURNAL } \\ \text { e-mail:jppi.puslitbangkan @ gmail.com } & \text { PENELITIAN } \\ \text { PERIKANAN } & \text { INDONESIA } \\ \text { JURNAL PENELITIANPERIKANANINDONESIA } & \text { Volume 23 Nomor 2 Juni 2017 } \\ \text { e-ISSN: 2502-6542 } & \\ \text { Nomor Akreditasi: 653/AU3/P2MI-LIPI/07/2015 }\end{array}$

\title{
MODEL ESTIMASI KONSUMSI BAHAN BAKAR KAPAL IKAN HUHATE DAN RAWAI TUNA
}

\section{ESTIMATION MODEL OF FUEL CONSUMPTION FOR POLE- LINE AND LONGLINE FISHING VESSELS}

\author{
Suryanto*1 dan Wudianto $^{1}$ \\ 'Pusat Riset Perikanan, Ancol Jakarta, Gedung BRSDM KP II, JI. Pasir Putih II, Ancol Timur, Jakarta Utara, \\ Indonesia-14430 \\ Teregistrasi I tanggal: 20 Juli 2017; Diterima setelah perbaikan tanggal: 19 September 2017; \\ Disetujui terbit tanggal: 25 September 2017
}

\begin{abstract}
ABSTRAK
Huhate dan rawai tuna merupakan alat tangkap utama untuk menangkap ikan tuna di perairan Indonesia. Hasil tangkapannya harus bersaing dalam perdagangan global dimana biaya bahan bakar merupakan faktor produksi yang dominan. Namun kebijakan Pemerintah terkait subsidi bahan bakar minyak terlalu sering berubah karena keterbatasan kemampuan keuangan Pemerintah. Disisi lain peraturan subsidi bahan bakar kapal perikanan yang berlaku kurang mencerminkan kondisi nyata armada perikanan Nasional. Oleh karena itu, perkiraan konsumsi bahan bakar yang diperlukan harus dilakukan secara cermat. Penelitian ini bertujuan untuk mengembangkan model estimasi konsumsi BBM mesin induk dan mesin bantu, khususnya untuk armada huhate dan rawai tuna. Uji model Kleppesto, Digernes dan Hollenbach digunakan untuk mengestimasi daya mesin induk armada huhate dan rawai tuna berdasarkan data SIPI (Surat ljin Penangkapan Ikan) dan pengukuran kecepatan kapal dilapangan. Hasil penelitian menunjukan bahwa model Kleppesto mendapatkan hasil lebih akurat. Selanjutnya model ini dipakai untuk memperkirakan faktor konsumsi BBM mesin induk dan mesin bantu $\left(\mathrm{C}_{\mathrm{bbm}}\right)$ dengan 2 skenario efisiensi quasi propulsive optimis dan pesimis. Hasil penelitian menunjukan, dengan kedua skenario tersebut, $\mathrm{C}_{\mathrm{bbm}}$ armada huhate dan rawai tuna didapatkan nilai $0,121-0,160$ dan $0,136-0,180\left(\frac{k g}{H_{\text {Jam }}}\right)$. Hal ini menjelaskan bahwa untuk mendapatkan faktor konsumsi BBM kapal ikan perlu memperhatikan jenis alat tangkap ikan yang digunakan.
\end{abstract}

Kata Kunci: Model estimasi; konsumsi; bahan bakar minyak (bbm); huhate; rawai tuna

\section{ABSTRACT}

Pole and line and long line are main fishing gear for catching tuna in Indonesian seas. Their catches must compete in global trade where as fuel cost is a dominant production factor. However the Government's policy on fuel subsidies has changed too often due to the limited financial capacity of the Government. In addition, the present regulation of fuel subsidy for fishing vessels does not reflect the real condition of the national fishing fleet. Thus, the estimation of the required fuel consumption must be done carefully. This paper aims to develop fuel consumption estimation model for pole and liner and tuna longliner. Based on the data of fishing licences and in situ vessel speeds measurements; Kleppesto, Digernes and Hollenbach models were used to estimate the required engine power of pole and liner and tuna longliner samples. The study indicates that Kleppesto model is more accurate compared to the other two. Using the scenario of optimistic and pessimistic quasi propulsive efficiencies, then the models were used to estimate the fuel oil consumption factor for main and auxiliary engines $\left(C_{b b m}\right)$ of the fleets. The research shows, $C_{b b m}$ of

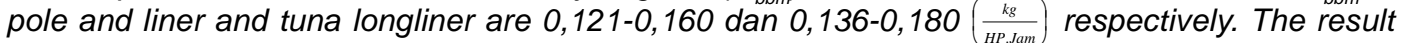
showed that fuel oil consumption factor of fishing vessel depends on fishing gear used.

Keywords: Estimation model; consumption; fuel oil; pole and lines; long lines 


\section{PENDAHULUAN}

Subsidi bahan bakar minyak (BBM) tampaknya telah menjadi beban keuangan Pemerintah yang sangat akut. Dalam 10 tahun terakhir telah diterbitkan 4 peraturan Presiden terkait penentuan harga bahan bakar minyak yaitu Perpres 55/2005; 9/2006; 15/2012 dan 191/2014. Subsidi BBM perikanan, khususnya kapal ikan menjadi lebih pelik terkait pembatasan ukuran kapal yang berhak menikmati subsidi tersebut. Kejadian ini terlihat dari adanya Perpres 15/ 2012 yang membatalkan Perpres 9/2006 dan memberlakukan kembali Perpres 55/2005. Terakhir Perpres 191/2014 tentang penyediaan, pendistribusian dan harga jual eceran bahan bakar minyak yang diikuti dengan peraturan menteri ESDM 39/2014 tentang perhitungan harga jual eceran BBM; menentukan harga BBM berdasarkan harga dasar minyak dunia dan nilai tukar rupiah terhadap USD. Permen ESDM tersebut tercatat telah direvisi dengan Permen 04/2015; 39/2015 dan 27/2016 yang pada intinya revisi tersebut merubah nilai subsidi Pemerintah, periode evaluasi harga jual bahan bakar dan pajak bahan bakar kendaraan bermotor (PBBKB). Bahkan perkembangan terbaru timbul wacana untuk menghapus subsidi BBM usaha perikanan, walau belum resmi menjadi kebijakan Pemerintah, asalkan ketersediaan BBM terjamin diseluruh pelosok sentra nelayan di tanah air (CNN Indonesia, 2017).

Dalam rangka menjamin kelancaran dan ketepatan pendistribusian bahan bakar minyak jenis tertentu untuk usaha perikanan, Kementerian Kelautan dan Perikanan menerbitkan Peraturan menteri KP No.13 tahun 2015 tentang petunjuk pelaksanaan penerbitan surat rekomendasi pembelian jenis bahan bakar minyak tertentu untuk usaha perikanan tangkap. Permen tersebut menetapkan konsumsi bahan bakar minyak mesin induk kapal ikan sebesar 0,165 $\left(\frac{\mathrm{kg}}{H P . d a m}\right)$ dan konsumsi bahan bakar mesin bantu ditetapkan $20 \%$ dari komsumsi mesin induk. Total konsumsi bahan bakar untuk kapal ikan ditetapkan tidak lebih dari $25 \mathrm{KI} /$ bulan.

Secara umum konsumsi bahan bakar kapal selain tergantung dengan daya mesin induk, juga tergantung jenis mesin (langkah dan kecepatan), beban (load factor) mesin, jenis bahan bakar yang dipakai (en- ergy density), tahun pembuatan mesin, lama operasi kapal, jenis alat tangkap bahkan tingkat perawatan mesin dan badan kapal serta kebiasaan awak dalam mengoperasikan kapal (Prado \& Dremiere, 1990; EPA, 2000; IMO, 2009; Trozzi, 2010; Faber et al., 2010; EPA, 2013; Basurko et al., 2013; HSVA, 2014; Basurko et al., 2016). Beberapa metode estimasi konsumsi bahan bakar kapal telah dikembangkan dengan menggunakan parameter tonase kapal (GT) dan daya mesin induk kapal (Georgakakia et al., 2005; Trozzi \& Vaccaro, 2006; Trozzi, 2010;) serta fuel consumption indicator yang memperhitungkan konsumsi bahan bakar terhadap beban mesin dan kecepatan kapal secara real time (Sala et al., 2010; Grimaldo et al., 2015). Namun permasalahan estimasi konsumsi bahan bakar kapal ikan Indonesia menjadi lebih rumit; karena pada umumnya menggunakan mesin darat yang telah dimodifikasi dan tidak bersertifikasi sehingga daya mesin yang dihasilkan tidak selalu identik dengan yang tertulis di spesifikasi mesin (Wibawa et al., 2015).

International Maritime Organization (IMO) secara berkala melakukan inventarisasi dan prediksi emisi gas rumah kaca (GRK) armada maritim International dengan 2 pendekatan utama fuel statistics (top down) dan activity based (bottom up). Pada pendekatan activity based, metode estimasi konsumsi bahan bakar dan faktor emisi yang dilakukan terus dikembangkan untuk meningkatkan ketelitian.

Dalam perspektif yang demikian, penelitian bertujuan untuk mendapatkan model estimasi konsumsi BBM mesin induk dan bantu, khususnya armada huhate dan rawai tuna, yang lebih akurat dengan mengadopsi dan memodifikasi metode IMO sehingga lebih sesuai untuk kebutuhan operasional kapal ikan.

\section{BAHAN DAN METODE Pengumpulan Data}

Data sekunder dimensi, tonase dan daya mesin induk kapal berdasarkan surat ijin penangkapan ikan (SIPI). Berdasarkan ketersediaan data primer kecepatan maksimum kapal, sampel yang digunakan dalam penelitian ini adalah 17 unit sampel armada huhate di Larantuka dan tiga unit armada rawai tuna di Cilacap; seperti terlihat pada Tabel 1. 
Tabel 1. Ukuran utama dan kecepatan kapal sampel

Table 1. Main dimensions and speed of sampling vessels

\begin{tabular}{|c|c|c|c|c|c|c|c|c|c|c|}
\hline \multirow[t]{2}{*}{ NO } & \multirow{2}{*}{$\begin{array}{c}\text { API } \\
\text { (Gear } \\
\text { Type })\end{array}$} & \multirow[t]{2}{*}{$\begin{array}{l}\text { Nama } \\
\text { (Name) }\end{array}$} & \multirow[t]{2}{*}{$\begin{array}{c}\text { Bahan } \\
\text { Material }\end{array}$} & $\begin{array}{l}\text { Panjang } \\
\text { (Length) }\end{array}$ & $\begin{array}{c}\text { Lebar } \\
\text { (Breadth) }\end{array}$ & $\begin{array}{c}\text { Tinggi } \\
(\text { Height })\end{array}$ & $\begin{array}{c}\text { Tonase } \\
\text { (Tonnage) }\end{array}$ & \multirow{2}{*}{$\begin{array}{c}\text { Merk Mesin } \\
\text { Induk } \\
\text { (Engine } \\
\text { Maker) }\end{array}$} & $\begin{array}{l}\text { Daya Mesin Induk } \\
\text { (Main Engine } \\
\text { Power) }\end{array}$ & \multirow{2}{*}{$\begin{array}{c}\begin{array}{c}\text { Kecepatan } \\
\text { (Speed) }\end{array} \\
\text { (Knot) }\end{array}$} \\
\hline & & & & (m) & (m) & (m) & (GT) & & (HP) & \\
\hline 1 & \multirow{17}{*}{ 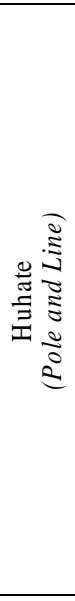 } & L.NB12B & FRP & 12,73 & 2,92 & 0,92 & 6 & Mitsubishi & 160 & 9,0 \\
\hline 2 & & L.BIS & FRP & 16,00 & 3,40 & 1,60 & 19 & Weichai & 140 & 8,0 \\
\hline 3 & & L.F18 & FRP & 13,52 & 4,00 & 1,60 & 22 & Volvo & 160 & 8,3 \\
\hline 4 & & L.Y & FRP & 19,19 & 3,65 & 1,60 & 26 & Yanmar & 105 & 7,5 \\
\hline 5 & & L.Fri & FRP & 12,73 & 2,70 & 0,92 & 6 & Mitsubishi & 190 & 9,5 \\
\hline 6 & & L.F25 & FRP & 13,52 & 4,00 & 1,60 & 22 & Volvo & 160 & 8,1 \\
\hline 7 & & L.NB09 & FRP & 12,73 & 2,92 & 0,92 & 6 & Mitsubishi & 160 & 9,0 \\
\hline 8 & & L.F24 & FRP & 13,52 & 4,00 & 1,60 & 22 & Volvo & 160 & 8,3 \\
\hline 9 & & L.F21 & FRP & 13,52 & 4,00 & 1,60 & 22 & Volvo & 160 & 8,4 \\
\hline 10 & & L.BS & Kayu & 19,62 & 4,18 & 1,71 & 30 & Mitsubishi & 220 & 9,0 \\
\hline 11 & & L.F19 & FRP & 13,52 & 4,00 & 1,60 & 22 & Volvo & 160 & 8,0 \\
\hline 12 & & S.D3A & FRP & 25,47 & 5,60 & 2,75 & 87 & Yuchai & 320 & 9,0 \\
\hline 13 & & S.Asp16 & Kayu & 22,46 & 4,28 & 2,26 & 49 & Nissan & 280 & 8,5 \\
\hline 14 & & K.SM & Kayu & 27,0 & 5,0 & 2,50 & 29 & Mitsubishi & 170 & 7,5 \\
\hline 15 & & B.D8 & Kayu & 24,40 & 4,95 & 2,46 & 94 & Cummins & 420 & 10,0 \\
\hline 16 & & B.D16 & FRP & 25,47 & 5,60 & 2,75 & 87 & Yuchai & 320 & 9,0 \\
\hline 17 & & B.BB & Kayu & 26,46 & 4,79 & 2,25 & 64 & Mitsubishi & 450 & 10,5 \\
\hline 18 & \multirow{3}{*}{ 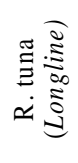 } & AR & FRP & 17,0 & 4,40 & 1,80 & 30 & Hinno & 120 & 7,5 \\
\hline 19 & & MB & Kayu & 12,85 & 6,00 & 1,45 & 62 & Mitsubishi & 300 & 8,5 \\
\hline 20 & & BW & Кауu & 18,03 & 4,32 & 1,72 & 29 & Nissan & 280 & 9,5 \\
\hline
\end{tabular}

Catatan:

$\mathrm{API}=$ Alat Penangkapan Ikan, $\mathrm{FRP}=$ fibre reinforced plastic, $\mathrm{HP}(\mathrm{SIPI})=$ daya mesin induk berdasarkan data pada SIPI kapal.

\section{Analisis Data}

Metode analisis yang diaplikasikan dalam penelitian ini adalah dengan mengadopsi metode yang dipakai oleh International Maritime Organization dalam memperkirakan emisi armada maritime dunia, yang didasarkan pada data Information Handling Services (HIS) Fairplay. IMO (2015) dalam memperkirakan tahanan total kapal menggunakan model Hollenbach (1998). Selain menggunakan model yang sama; penelitian ini juga mengaplikasikan model Digernes (1982) dan Kleppesto (2015) yang lebih spesifik untuk kapal ikan. Tahapan analisis data penelitian mencakup;

a) Memperkirakan daya mesin induk yang terpasang di kapal dibandingkan dengan data berasal dari SIPI : ( $\left.\mathrm{HP}_{\text {Mode/SIPI }}\right)$ dengan tahapan

i. $H \rho_{\text {Model }}=P_{t}^{*} \eta_{q \rho}$

- $\eta_{\mathrm{q} \rho}=\eta_{\text {hull }} * \eta_{\text {behind }} * \eta_{\text {relative rotative }} * \eta_{\text {open }} * \eta_{\text {shaft }}$

- $\eta_{q p}$ : quasi propulsive eff (seknario optimis \& pesimis)

(Sampson. 2008)

- $P_{t}=R_{t} * V_{\max }$
- $R_{t}=R_{f}+R_{w}+R_{\text {add }}($ Hollenbach ; Digernes ; Kleppesto $)$

- $R_{t}=$ tahan total

- $R_{f}=$ tahanan gesek lambung kapal secara umum tergantung dari kecepatan kapal, luas permukaan basah lambung kapal, berat jenis air laut dan koefisien gesek lambung yang bervariasi terhadap Reynolds number.

- $R_{w}=$ wave making resistance secara umum dipengaruhi oleh parameter-parameter bentuk lambung, Froude number, letak titik tekan gaya keatas (centre of buoyancy) dan berat jenis air laut. - $R_{\text {add }}=$ tahanan tambahan (angin, gelombang dII). Tahanan angin secara umum dipengaruhi oleh kecepatan kapal relatif terhadap kecepatan angin, luas bangunan atas relatif terhadap arah angin dan berat jenis udara. Sedangkan tahanan gelombang secara umum dipengaruhi displacement, kecepatan kapal, Beaufort number dan arah kapal relatif terhadap arah gelombang/ angin.

- $V_{\text {max }}=$ kecepatan maksimum (pengukuran in situ)table.1.

${ }^{-H P_{\text {Model }} / \text { SIPI }}=\frac{H P_{(\text {Hollenbach }, \text { Digers, Kleppesto })}}{\mathrm{HP}_{\text {SIPI }}}$;

merupakan faktor yang mencerminkan daya maksimum mesin induk secara riil dibandingkan dengan daya mesin induk yang tertulis di SIPI kapal. 
b) Memperkirakan faktor konsumsi bahan bakar mesin induk dan mesin bantu

i. Daya mesin pada variasi operasi kapal dihitung berdasarkan;

$$
P_{t}=\frac{P \bmod \left(\frac{T_{t}}{T_{S I P I}}\right)^{\frac{2}{3}}\left(\frac{V_{t}}{V_{\max }}\right)^{\eta}}{\eta_{w} \eta_{f}}
$$

- $P_{\text {mod }}, \mathrm{V}_{\text {max }}, \mathrm{T}_{\text {SIPI }}$ adalah daya mesin (HP) yang diperoleh berdasarkan simulasi model dengan kecepatan $\mathrm{V}_{\text {max }}$ (knot) (Tabel.1) dan sarat kapal $\mathrm{T}_{\text {SIPI }}$ (meter - lihat asumsi).

- $P_{t}, \mathrm{~V}_{\mathrm{t}}, \mathrm{T}_{\mathrm{t}}$ adalah daya mesin (HP) pada kecepatan $\mathrm{V}_{\text {steaming }}$ atau $\mathrm{V}_{\text {fishing }}$ (knot - hasil pengukuran insitu) dan sarat kapal $T_{t}$ (meter - lihat asumsi).

- $\eta_{w}, \eta_{f}$ efisiensi propulsive karena pengaruh gelombang dan kekasaran lambung (diasumsikan tidak berubah terhadap modus operasi); dimana $\eta_{\mathrm{w}}=1,0$ dan $\eta_{\mathrm{f}}=0,95$ (Sampson. 2008).

- $\mathrm{n}=3$; konstanta yang mencerminkan hubungan kecepatan dan daya mesin kapal (Faber et al., 2010)

ii. Specific fuel oil consumption pada variasi beban mesin (Jalkanen et al., 2009; 2012). $\mathrm{SFOC}_{\text {(steaming,fishing) }}=0,455 \mathrm{EL}^{2}-0,71 \mathrm{EL}+1,28-\mathrm{EL}$ adalah beban mesin (\%)

iii. Konsumsi bahan bakar pada tahap operasi

$F C_{(\text {stea min } g, \text { fishing })}=\operatorname{SFOC}_{(\text {based })} * \operatorname{SFOC}_{(\text {stea min } g, \text { fishing })} * T_{(\text {stea min } g, \text { fishing })}$

- SFOC ${ }_{\text {based }}$ (Jalkanen et. al2009; 2012)

- $\mathrm{T}_{\text {steaming }}=10 \%$ (huhate); 34\% (rawai tuna). (Suryanto et.al, 2015; 2016).

- $\mathrm{T}_{\text {fishing }}=90 \%$ (huhate); 66\% (rawai tuna). (Suryanto et al., 2015; 2016)

- Konsumsi bahan bakar mesin bantu $=20 \%$ mesin induk (Suryanto et al., 2015)

iv. Faktor konsumsi bahan bakar mesin kapal

$$
C_{b b m}=\frac{F C_{\text {steamin } g+F C_{\text {fishing }}}}{H P_{\text {SIPI }}}\left(\frac{\mathrm{kg}}{H P} \cdot \mathrm{jam}\right)
$$

Asumsi

- Mesin induk kapal dibuat pada tahun 1984-2000, jenis 4 langkah, medium speed diesel engine (MSDE) berbahan bakar solar (marine diesel oilMDO dengan berat jenis $0,85 \mathrm{~kg} / \mathrm{ltr}$ ).

- Nelayan pada saat menuju daerah penangkapan dari pelabuhan atau kembali ke pelabuhan dari daerah penangkapan (steaming), biasanya menjalankan mesin induk pada posisi full throttle maka kecepatan kapal pada saat tersebut identik dengan kecepatan yang terjadi pada beban mesin $100 \%$ MCR

- Sarat kapal ditentukan 80\% dari tinggi geladak karena tidak terdapat pada data SIPI. Sarat kapal diasumsikan tidak berubah pada setiap kondisi operasi.

- Beban mesin bantu tidak tergantung modus operasi kapal

\section{HASIL DAN BAHASAN \\ Hasil}

Pada tahun 2010-2014, total produksi tuna Indonesia meningkat dari 905.700 ton menjadi 1.326.126 ton, dengan peningkatan produksi $18,2 \%$ per tahun untuk tuna; 9,3\% per tahun untuk cakalang dan 7,3 $\%$ per tahun untuk tongkol (Pusdatin, 2015). Armada huhate berkembang perairan Timur Indonesia pada tahun 1970-an namun pada akhir tahun 1990 mengalami penurunan karena harus bersaing dengan armada pukat cincin yang beroperasi diperairan laut Sulawesi dan sekitarnya. Akibatnya armada huhate yang memiliki tonase kurang dari 30 GT banyak yang tidak beroperasi. Nelayan kemudian membangun armada huhate berukuran besar (50-80 GT) sehingga dapat beroperasi laut Maluku, teluk Tomini dan sekitarnya. Armada huhate dalam operasinya bersifat aktif dengan mengejar gerombolan ikan yang ditandai dengan banyaknya gerombolan burung diatas permukaan air, kemudian dirangsang dengan lemparan umpan hidup dan semprotan air. Penangkapan ikan dilakukan sepanjang tahun, baik musim barat, peralihan, maupun musim timur (Nugraha \& Rahmat, 2008).

Waktu penangkapan terbaik sekitar jam 05:3009:00 dan 16:00-18:00 (WWF-Indonesia, 2015). Setiyawan et al., (2016) menambahkan, empat faktor utama yang berpengaruh terhadap hasil tangkapan armada huhate adalah jenis umpan hidup, suhu permukaan laut, jumlah pemancing dan daerah penangkapan. Suprianto et al, (2012) lebih spesifik menunjukan daerah penangkapan armada huhate di laut Maluku berada di sebelah Utara pada posisi $0^{\circ}$ 00' 5,48''LU - $1^{0} 16^{\prime} 2,12$ '" BT dan di sebelah Timur pada posisi $124^{\circ} 04^{\prime} 5.48^{\prime \prime}$ LU - $126^{\circ} 22^{\prime}$ 5,38' BT serta musim penangkapan utama pada bulan April dan bulan Juli - September (Suprianto et al., 2012).

Perikanan rawai tuna diperkenalkan di Indonesia sejak 1930-an oleh nelayan Jepang, namun perikanan tersebut beroperasi secara komersial baru 30 tahun kemudian (Proctor et al., 2003 dalam Jatmiko et. al., 2016). Pada tahun 1982 di Indonesia terdapat 39 armada rawai tuna yang sebagian besar berpangkalan 
di Bali dan beroperasi di samudera Hindia sedangkan sisanya berpangkalan di Ambon dan Aertembaga dengan daerah operasi di Laut Banda (Simorangkir, 2000 dalam Nugraha \& Hufiadi, 2012). Pada awal tahun 2000 diperkirakan jumlah armada rawai tuna yang beroperasi di seluruh perairan Indonesia sekitar 1.400 unit; dimana 1.200 unit beroperasi di Samudera Hindia (Pusat Riset Perikanan Tangkap, 2002 dalam Nugraha \& Hufiadi, 2012). Namun jumlah armada yang teregistrasi baru sebanyak 1.256 unit (Irianto et al., 2013 dalam Jatmiko et al., 2016). Peningkatan yang sangat signifikan tersebut akibat banyaknya armada dari Taiwan dan China yang melakukan re-flagging ke Indonesia (Sadiyah \& Prisantoso, 2011 dalam Jatmiko et al., 2016).

Daerah penangkapan armada rawai tuna Indonesia adalah di $108-118^{\circ}$ BT dan 8-220 LS; dimana lebih dari $70 \%$ diantaranya melakukan penangkapan di luar ZEE Indonesia (Wudianto et al., 2003). Pada umumnya armada rawai tuna yang berpangkalan di Cilacap memiliki tonase lebih kecil, sehingga daerah penangkapan armada tersebut lebih terbatas dan dekat yaitu di $108-111^{\circ}$ BT dan $9-15^{\circ}$ LS (Triharyuni \& Prisantoso, 2012).

Selain penambahan jumlah armada, kapasitas penangkapan armada rawai tuna juga meningkat melalui perubahan alat tangkap. Pada kurun waktu 2006-2014 jumlah mata pancing menurun dari 1.500 buah menjadi 1.100 dengan lama waktu tebar menurun dari 6 menjadi 4 jam namun lama waktu perendaman meningkat dari 4 menjadi 8 jam, panjang tali cabang bertambah dari 23 menjadi 26 meter, tali pelampung dari 24 menjadi 28 meter dan jumlah pancing antar pelampung mengalami penurunan dari 19 menjadi 11 buah (Jatmiko et al., 2016). Akibat dari peningkatan kapasitas penagkapan tersebut ratarata berat ikan yang tertangkap, hook rate dan CPUE cenderung menurun. Pada tahun 1995 berat ikan ratarata yang tertangkap $32 \mathrm{~kg}$ dengan hook rate 0,86 dan CPUE $280 \mathrm{~kg} /$ trip, namun pada tahun 2005 berat rata-rata ikan tertangkap menjadi $29 \mathrm{~kg}$ dengan hook rate 0,45 dan CPUE 172 kg/trip (Nugraha \& Hufiadi, 2012).

\section{Bahasan}

Hasil estimasi model Kleppesto, Digernes dan Hollenbach didapatkan rerata daya mesin induk yang terpasang dikapal adalah $0,794_{+} 2,6 \% ; 0,389_{+} 3,3 \%$ dan $0,355_{4} 4,9 \%$ dari daya mesin induk berdasarkan SIPI. Berdasarkan model Kleppesto nilai konstanta $H P_{\text {Model } / \text { SIPI }}$ bervariasi dari 0,486-0,97, sedangkan model Digernes dan Hollenbach berturut-turut antara 0,25-0,57 dan 0,25-0,81; hasil selengkapnya dapat dilihat di Lampiran II. Tampak bahwa model Kleppesto lebih baik dalam mengestimasikan besar tenaga mesin induk yang terpasang dibandingkan dengan data di SIPI, seperti terlihat pada Gambar 1.
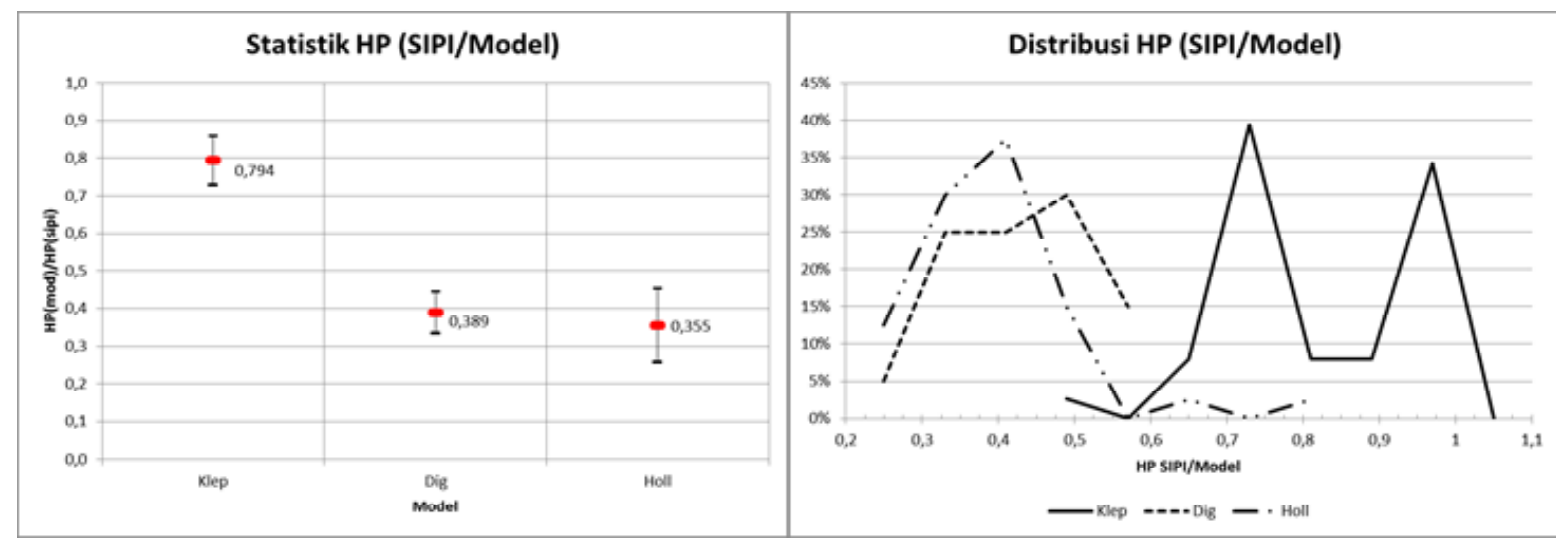

Gambar. 1. Perbandingan daya mesin induk berdasarkan SIPI dan model. Statistik (kiri) dan distribusi (kanan). Figure. 1. Comparation of main engine power between fishing license and models. Statistical results (left) and distribution (right).

Tanpa memperhatikan perbedaan jenis alat tangkap dengan asumsi efisiensi quasi propulsive optimis dan pesimis, faktor konsumsi bahan bakar mesin kapal $\left(C_{b b m}\right)$ dengan model Hollenbach (1998), Digernes (1982) dan Kleppesto (2015) didapatkan nilai $(0,066-0,088) ;(0,071-0,095)$ dan $(0,123-0,163)\left(\frac{\mathrm{kg}}{\mathrm{HP} \text {.Jan }}\right)$. Dengan model yang sama berdasarkan jenis alat tangkap, konsumsi bahan bakar armada huhate berturut-turut adalah 0,120-0,160;0,070-0,093 dan 0,061-

$0,078\left(\frac{k g}{H P . J a n}\right)$. Sedangkan untuk armada rawai tuna nilai tersebut adalah $0,136-0,180 ; 0,079-0,104$ dan 0,092$0,109\left(\frac{\mathrm{kg}}{H \text { H.Jam }}\right)$; hasil selengkapnya dapat dilihat di Lampiran II. Secara umum $\mathrm{C}_{\mathrm{bbm}}$ armada rawai tuna $12 \%$ lebih tinggi dari armada huhate berdasarkan model Kleppesto dan Digernes. Berdasarkan model Hollenbach nilai tersebut menjadi $45 \%$ seperti terlihat pada Gambar 2. 


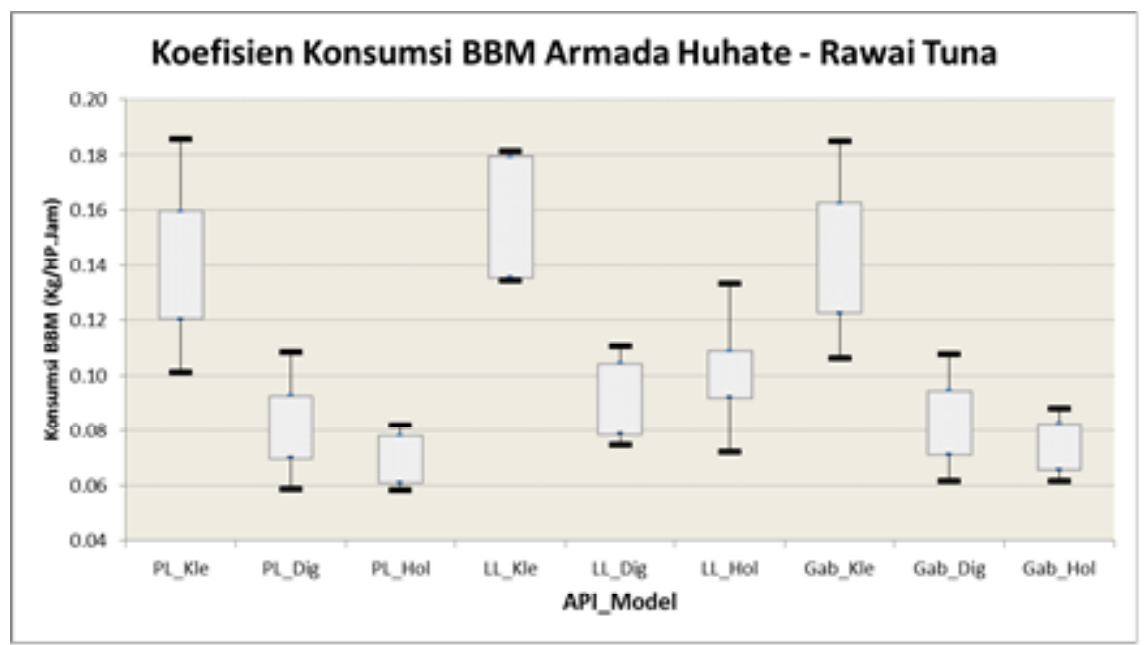

Gambar. 2. Estimasi koefisien konsumsi bahan bakar armada huhate (PL), rawai tuna (LL) dan gabungan (Gab) berdasarkan model Kleppesto, Digernes dan Hollenbach dengan skenario efisiensi quasi propulsive pesimis dan optimis.

Figure. 2. Estimated specific fuel oil consumption for pole and line (PL), longliner ( $L L)$ and combined (Gab) based on Kleppesto, Digernes and Hollenbach models with pessimistic and optimistic quasi propulsion efficiency scenario.

Schneekluth \& Bertram (1998) menyebutkan model Hollenbach termasuk katagori general applicability. IMO memakai model tersebut untuk memperkirakan emisi armada laut Internasional berdasarkan database registrasi kapal Information Handling Services (IHS) Fairplay, termasuk diantaranya 22.130 unit kapal kapal ikan dengan rerata daya mesin 1.280 HP (IMO, 2015). Namun studi menunjukan $65 \%$ sampel kapal ikan yang dianalisis tidak memenuhi rentang validitas perbandingan panjang terhadap lebar kapal dan Froude number yang ditentukan Hollenbach. Hal ini dapat diartikan model Hollenbach kurang sesuai untuk memodelkan kapal sampel yang memiliki lebar relatif lebih besar dibandingkan panjang kapal, namun memiliki rasio gaya inersia terhadap gaya gravitasi (Froude number) relatif tinggi. Alasan tersebut yang menyebabkan konstanta model Hollenbach memiliki sebaran terlebar $(0,25 \div 0,81)$ dan model Digernes mendapatkan sebaran tersempit $(0,25 \div 0,57)$. Kleppesto (2015) mengembangkan model berdasarkan model Digernes dengan menambahkan data kapal ikan terbaru. Berdasarkan model Kleppesto sebaran ${ }^{H P}$ Model ISIPI lebih terpusat dibandingkan model Hollenbach $(0,486 \div 0,97)$. Studi menunjukan seluruh sampel kapal masuk dalam rentang validitas Kleppesto untuk parameter Froude number walaupun $50 \%$ diantaranya melebihi rentang validitas untuk perbandingan panjang terhadap lebar kapal.

Seknario efisiensi quasi propulsive pesimis lebih dipilih karena tidak adanya standar perencanaan dan pembangunan kapal ikan, sehingga bentuk lambung, baling-baling, sistim gear box dan poros baling-baling tidak sempurna. Berdasarkan skenario tersebut,
$\mathrm{C}_{\text {bbm }}$ gabungan alat tangkap huhate dan rawai tunai, bervariasi $0,163_{ \pm} 1 \%, 0,095_{ \pm} 16,3 \%$ dan $0,08_{ \pm} 13,6 \%$ $\left(\frac{\mathrm{kg}}{H P . J a m}\right)$ berdasarkan model Kleppesto, Digernes dan Hollenbach. Sementara Prado \& Dremiere (1990) memberikan estimasi kebutuhan bahan bakar $\left(\mathrm{C}_{\mathrm{bbm}}\right)$ kapal ikan 0,170-0,200 $\left(\frac{\mathrm{kg}}{\mathrm{HP.Jam}}\right)$ untuk mesin diesel tanpa turbo charger dengan berat jenis bahan bakar $0,84 \mathrm{~kg} / \mathrm{ttr}$. Secara global $\mathrm{C}_{\mathrm{bbm}}$ armada perikanan artisanal, pantai dan lepas pantai berturut-turut 0,134, 0,160 dan $0,179\left(\frac{\mathrm{kg}}{H p \text { Jam }}\right)$. Sementara rerata $\mathrm{C}_{\mathrm{bbm}}$ armada perikanan China dan Korea Selatan 0,209 dan 0,194 $\left(\frac{\mathrm{kg}}{\text { HP.Jam }}\right) \quad$ (Muir, 2015). Berdasarkan informasi tersebut diperkirakan $\mathrm{C}_{\mathrm{bbm}}$ dalam Permen KP No.13 tahun 2015 adalah rerata dari ketiga kelas armada perikanan dunia dan lebih hemat energi dari pada armada perikanan China maupun Korea Selatan. Trozzi \& Vaccaro (1998) dengan data Lloyd's Maritime Information Services Ltd (sekarang IHS Fairplay) memformulasikan $\mathrm{C}_{\mathrm{bbm}}$ kapal ikan sebagai $1,9387+0,00448^{*} \mathrm{GT}$ (ton/hari); yang kemudian diperbaiki menjadi 1,2744+0,0062*GT-6,4603E$7^{\star} \mathrm{GT}^{2}+5,5193 \mathrm{E}-11^{*} \mathrm{GT}^{3}$ ton/hari (Trozzi \& Vaccaro, 2006).

Hasil penelitian ini jika diperbandingkan dengan kedua formula tersebut didapatkan 68 dan $55 \%$ lebih tinggi. Hal ini dapat terjadi karena kapal yang dipakai dalam penelitian Trozzi memiliki tonase lebih dari 100 GT (Trozzi \& Vaccaro, 2006), sedangkan tonase kapal sampel bervariasi 6-94 GT. Trozzi (2010) menunjukan korelasi antara besar daya mesin induk terhadap 
tonase armada perikanan dunia pada tahun 2010. Berdasarkan korelasi tersebut didapatkan daya mesin induk berdasarkan data SIPI masupun model Kleppesto untuk kapal bertonase kurang dari 50 GT lebih besar dari armada perikanan dunia, seperti terlihat pada Lampiran I. Hal tersebut juga mengindikasikan terjadinya manipulasi tonase kapal sampel seperti juga didapatkan oleh Badrudin (2007), Suryanto (2012), KPK (2014) dan Menkumham (2015).

Basurko et al (2013) menginformasikan $\mathrm{C}_{\mathrm{bbm}}$ armada huhate di Spanyol Utara 0,045 $\left(\frac{\mathrm{kg}}{\mathrm{HPJJam}}\right)$, dimana hasil tersebut hanya 38\% dari hasil model Kleppesto. Hal tersebut terjadi karena kapal yang digunakan sebenarnya adalah kapal pukat cincin yang dioperasikan dengan menggunakan alat tangkap huhate serta tidak memperhatikan konsumsi bahan bakar mesin bantu kapal (Basurko et. al, 2013). Sedangkan Peterson et.al (2014) menginformasikan $\mathrm{C}_{\mathrm{bbm}}$ pancing rawai penangkap sablefish (Anoplopoma fimbria), Pacific halibut (Hippoglossus stenolepis) dan Greenland turbot (Reinhardtius hippoglossoides) di

Alaska adalah 0.0543 dan 0,0593 $\left(\frac{\mathrm{kg}}{\mathrm{HP.Jam}}\right)$. Sementara Tyedmers (2001) mendapatkan $\mathrm{C}_{\mathrm{bbm}}$ rawai tuna di Atlantik utara $0.0995\left(\frac{\mathrm{kg}}{\mathrm{HPJJam}}\right)$ (data diolah). Dimana $\mathrm{C}_{\mathrm{bbm}}$ model Kleppesto $80 \%$ lebih besar dari pancing rawai di Atlantik. Secara lebih umum Muir (2015) mendapatkan $\mathrm{C}_{\mathrm{bbm}}$ armada pelagis pasif di Perancis $0,571\left(\frac{\mathrm{kg}}{H . J \mathrm{Jam}}\right)$; yang berarti $220 \%$ lebih besar dari $\mathrm{C}_{\mathrm{bbm}}$ Kleppesto. Namun jenis alat tangkap tersebut mencakup jenis alat tangkap yang beragam seperti jaring insang, trammel net, handline, trolling, pancing rawai, bubu dan trap (Cochrane \& Garcia, 2009). Sala et al, (2011) meneliti $\mathrm{C}_{\mathrm{bbm}}$ dua kapal pelagis trawl yang relatif sama; satu unit terbuat baja dengan menggunakan controllable pitch propeller(cpp) dan kapal terbuat dari kayu dengan menggunakan fixed pitch prolller; dengan menggunakan ukuran alat tangkap yang sama.

Hasil menunjukan $\mathrm{C}_{b b m}$ kapal berbahan baja $19 \%$ lebih rendah dari pada kapal kayu. Hal tersebut menunjukan bahwa $\mathrm{C}_{\mathrm{bbm}}$ selain bervariasi terhadap daya mesin induk, juga bervariasi terhadap dimensi kapal (dimensi atau tonase), teknologi kapal, jenis alat tangkap, target dan daerah tangkapan. Namun Grimaldo et.al (2015) dalam penelitian dengan menggunakan satu kapal dengan beberapa jenis alat tangkap trawl, menunjukan $\mathrm{C}_{\mathrm{bbm}}$ tidak berbeda signifikan jika $\mathrm{C}_{\mathrm{bbm}}$ dihitung berdasarkan daya mesin induk dan kecepatan kapal secara real time. Penelitian dengan metode yang sama menjadi tantangan dimasa depan walaupun memerlukan peralatan yang mahal.

\section{KESIMPULAN}

Berdasarkan model Kleppesto diperoleh $\mathrm{C}_{\mathrm{bbm}}$ armada huhate antara 0,121-0,160 $\left(\frac{\mathrm{kg}}{\mathrm{HP} \cdot \mathrm{Jam}}\right)$ dan armada rawai tuna $0,136-0,180\left(\frac{\mathrm{kg}}{H P . \mathrm{Jam}}\right)$. $\mathrm{C}_{\mathrm{bbm}}$ armada huhate baik dengan skenario quasi propulsive efficiency pesimis maupun optimis lebih kecil dari pada yang tertuang dalam Permen KP no.13 tahun 2015. Sedangkan pada armada rawai tuna yang tertuang dalam permen tersebut berada diantara kedua skenario quasi propulsive efficiency. Model estimasi konsumsi bahan bakar yang digunakan dalam penelitian ini lebih teliti dibandingkan dengan model pada peraturan yang ada karena model ini memperhatikan : (1) jenis alat tangkap yang dicerminkan dalam parameter porsi waktu dan kecepatan kapal pada tahap steaming dan fishing, (2) spesifikasi teknis mesin induk : kecepatan (low, medium, high speed), jumlah langkah (2, 4 cycle), kelengkapan (turbo charger), jenis bahan bakar yang digunakan (fuel energy density) dan tahun pembuatan yang berpengaruh pada brake specific fuel oil consumption (BSFOC) mesin dan (3) menggunakan daya mesin induk riil (berdasarkan model), mengingat pada umumnya mesin induk kapal ikan tidak bersertifikat uji/mesin darat bekas). Namun, untuk kemudahan aplikasi dilapangan, koefisien konsumsi bahan bakar $\left(\mathrm{c}_{\mathrm{bbm}}\right)$ diperoleh dengan membandingkan estimasi konsumsi bahan bakar terhadap tenaga mesin induk berdasarkan SIPI. Seperti terlihat pada metodologi; maka $\mathrm{C}_{b b m}$ dapat berubah jika terjadi perubahan pola operasi (steaming dan fishing).

\section{PERSANTUNAN}

Penelitian ini adalah bagian dari penelitian Perhitungan Jejak Karbon Nelayan di Pusat Penelitian Perikanan (d/h Pusat Penelitian dan Pengembangan Perikanan)yang dilaksanakan pada tahun anggaran 2015-2016.

\section{DAFTAR PUSTAKA}

Badrudin. (2007). "Mark Down" Ukuran Kapal Perikanan Mempersulit Pengelolaan Perikanan (p.28). Komisi Nasional Pengkajian Sumber Daya Ikan. Badan Riset Kelautan dan Perikanan.

Basurko, O.C., Gabina, G., \& Uriondo, Z. (2013). Energy performance of fishing vessels and potential savings. Journal of Cleaner Production (54). $30-40$ 
Basurko, O.C., Gabina, G., \& Quincoces, I. (2016). Fuel consumption monitoring in fishing vessels and its potential for different stakeholders. In Shipping in Changing Climates Conference 2016, Newcastle, The United Kingdom. Newcastle University. http://www.lowcarbonshipping.co.uk/files/ u c l_a d m i n / S C C \% 202016/ Oihane_Basurko__ Quincoces_2016_F uel_consumption_monitoring_in_fishing_vessels_and its_potential_for_d ifferent_stakeh.pdf. Diunggah 30 Maret 2017.

CNN Indonesia (2017). Menteri Susi Minta Subsidi BBM Nelayan Dihapuskan. https:// ww w. cnnindonesia.com/ekonomi/ 20170731183642-92-231540/menteri-susi-mintasubsidi-bbm-nelayan-dihapuskan. Diunggah 18 September 2017.

Cochrane, K.L., \& Garcia, S.M. (2009). A Fishery Manager's Guidebook. Second Edition (p.544). The Food and Agriculture Organization of the United Nations and Wiley-Blackwell.

Digernes, T. (1982). An analytical approval to evaluating fishing vessel design and operation. Dr. Ing dissertation. Institute of Computer Science. Norwegian Institute of Technology. $236 \mathrm{p}$.

EPA(Environmental Protection Agency). (2000). Analysis of Commercial Marine Vessels Emissions and Fuel Consumption Data. 158 p.

EPA (Environmental Protection Agency). (2013). Emission Inventory Guide Book (p. 40). International navigation, national navigation, national fishing.

Faber, J., Freund, M., Köpke, M., \& Nelissen, D. (2010). Going slow to reduce emissions (p. 29). Sea at risk.

Georgakakia, A., Coffeya, R.A., Lockb, G., \& Sorenson, S.C. (2005). Maritime air pollutant emission modelling. Atmospheric Environment (39). 2357-2365.

Grimaldo, E., Pedersen, R., \& Sistiga, M. (2015). Energy consumption of three different trawl configurations used in the Barents sea demersal trawl fisheries. Fisheries research (165). 71-73.

Hollenbach, K. U. (1998). Estimating resistance and propulsion for single screw and twin screw ships. Ship Technology Research. (45) 2.
HSVA (Hamburgische Schiffbau-Versuchsanstalt). (2014). Calculation of Fuel Consumption Per Mile for Various Ship Types and Ice Conditions in Past, Present and in Future (p. 39). Report D 2.42. Seventh Framework Programme.

IMO (International Maritime Organization). (2009). Second IMO GHG study (p. 289). Update of the 2000 IMO GHG Study.

IMO (International Maritime Organization). (2015). Third IMO GHG Study 2014. Executive summary and final report. $327 \mathrm{p}$.

Jalkanen, J.P., Brink, A., Kalli, J., Pettersson, H., \& Stipa, T. (2009). A modelling system for exhaust emissions of marine traffic and its application in Baltic sea area. Atmospheric Chemistry and Physic (9). 9209-9223.

Jalkanen, J.P., Johansson, L., Kukkonen, J., Brink, A., Kalli, J., \& Stipa,T. (2012). Extension of an assessment model of ship traffic exhaust emissions for particulate matter and carbon monoxide. Atmospheric Chemistry and Physics (12). 26412659.

Jatmiko, I., Rochman, F., \& Wujdi, A. (2016). Dinamika perubahan metode penangkapan rawai tuna di samudera Hindia. J. Lit. Perikan. Ind. 22(3) .173-180

Kleppesto, K. (2015). Empirical prediction of resistance of fishing vessels. Master thesis in Marine Technology. Norwegian University of Science and Technology. 87 p.

KPK (Komisi Pemberantasan Korupsi). (2014). Laporan Hasil Kajian System Pengelolaan Ruang Laut dan Sumber Daya Kelautan (p. .70). Deputi Bidang Pencegahan. Direktorat Penelitian dan Pengembangan.

Menkumham (Kementerian Hukum dan HAM). (2015). Laporan Akhir Tim Analisis dan Evaluasi Hukum Bidang Perikanan (p.176). Badan Pembinaan Hukum Nasional.

Muir, J.F. (2015). Fuel and energy use in the fisheries sector. Approaches, inventories and strategic implications. FAO Fisheries and Aquaculture CircularNo. C1080. 107 p.

Nugraha, B., \& Rahmat, E. (2008). Status perikanan huhate (pole and line) di Bitung Sulawesi utara. J. Lit. Perikan. Ind. 13(3). 311-318. 
Nugraha, B \& Hufiadi. 2012. Produktivitas perikanan tuna longline di Benoa (studi kasus: PT. Perikanan Nusantara). Marine Fisheries. 3(2). 135-140.

Peraturan Menteri ESDM No. 39 tahun 2014 tentang perhitungan harga jual eceran bahan bakar minyak

Peraturan Menteri ESDM No. 04 tahun 2015 tentang perubahan atas peraturan menteri energy dan sumber daya mineral nomor 39 tahun 2014 tentang perhitungan harga jual eceran bahan bakar minyak

Peraturan Menteri ESDM No. 39 tahun 2015 tentang perubahan kedua atas peraturan menteri energy dan sumber daya mineral nomor 39 tahun 2014 tentang perhitungan harga jual eceran bahan bakar minyak

Peraturan Menteri ESDM No. 27 tahun 2016 tentang perubahan ketiga atas peraturan menteri energy dan sumber daya mineral nomor 39 tahun 2014 tentang perhitungan harga jual eceran bahan bakar minyak

Peraturan Menteri ESDM No. 36 tahun 2016 tentang percepatan pemberlakuan satu harga jenis bahan bakar minyak tertentu dan jenis bahan bakar minyak khusus penugasan secara Nasional

Peraturan Menteri ESDM No. 34 tahun 2014 tentang harga jual eceran dan konsumen pengguna jenis bahan bakar minyak tertentu

Peraturan Menteri Kelautan dan Perikanan No. 13 tahun 2015 tentang petunjuk pelaksanaan penerbitan surat rekomendasi pembelian jenis bahan bakar minyak tertentu untuk usaha perikanan tangkap

Peraturan Presiden No.55 tahun 2005 tentang harga jual eceran bahan bakar minyak dalam negeri

Peraturan Presiden No. 9 tahun 2006 tentang perubahan atas peraturan Presiden nomor 55 tahun 2005 tentang harga jual eceran bahan bakar minyak dalam negeri

Peraturan Presiden No. 15 tahun 2012 tentang harga jual eceran dan konsumen penggunajenis bahan bakar minyak tertentu

Peraturan Presiden No. 191 tahun 2014 tentang penyediaan, pendistribusian dan harga jual eceran bahan bakar minyak.
Peterson, M.J., Mueter, F., Criddle, K, \& Haynie, A.C. (2014). Killer whale depredation and associated costs to Alaskan sablefish, Pacific halibut and Greenland turbot longliners. Plos Ones. 9(2). 12.

Prado, J., \& Dremiere, P.Y. (1990). Fisherman's Workbook (p.185). Fishing Technology Service. Fishery Industries Division. FAO.

PUSDATIN (Pusat Data Statistik dan Informasi). (2015). Analisis data pokok kelautan dan perikanan (p.167). Kementerian Kelautan dan Perikanan

Sala, A., de Carlo, F., \& Buglioni, G. (2010). Coriolis Fuel Mass Flow Metering for Fishing Vessels. 1st International Symposium on Fishing Vessel Energy Efficiency -Vigo, Spain. (Presentation)

Sala, A., de Carlo, F., Buglioni, G., \& Lucchetti, A. (2011). Energy performance evaluation of fishing vessels by fuel mass flow measuring system. Ocean Engineering (38). 804-809.

Sampson, R. (2008). Propeller hull interaction. Resistance and propulsion. School of marine science and technology. New Castle University. (Presentation). $43 \mathrm{p}$.

Schneekluth, H., \& Bertram, V. (1998). Ship Design for Efficiency and Economy (p.226). 2nd edition. Oxford: Butterworth-Heinemann.

Setiyawan, A., Sadiyah, L., \& Samsuddin, S. (2016). Faktor-faktor penting yang mempengaruhi cpue (catch per unit effort) perikanan huhate berbasis di Bitung. J. Lit. Perikan. Ind. 22(1). 43-50.

Suprianto, D., Reppie, E., \& Budiman, J. (2012). Daerah penangkapan ikan dari kapal huhate yang berpangkalan di Pelabuhan Perikanan Pantai Belang. Jurnal IImu dan Teknologi Perikanan Tangkap 1(2): 57-62.

Suryanto. (2012). Kajian Standarisasi Pengukuran Tonase Kapal Pukat Cincin Yang Beroperasi di Selat Bali dan Dampaknya pada Pungutan Hasil Perikanan. In Seminar Nasional Perikanan Indonesia (p. 120-129). Hasil Penelitian Perikanan dan Kelautan. Sekolah Tinggi Perikanan Jakarta.

Suryanto., Wudianto., Nugroho, D., Sumiono, B., Widodo, A.A., Puspasari, R., Oktaviani,......................... Watupongoh, N.N.J. (2015). Laporan akhir. Perhitungan jejak karbon 
nelayan. Pusat Penelitian dan Pengembangan Perikanan. Badan Penelitian dan Pengembangan Kelautan dan Perikanan. Kementerian Kelautan dan Perikanan. $92 \mathrm{p}$.

Suryanto., Nugroho, D., Sumiono, B., Susanto, K., Hargiyatno, I.T., Anggawangsa, R., Akbar, R.M.A., \& Wibowo, S. (2016). Laporan akhir. Jejak karbon perikanan tuna cakalang tongkol di wpp 572 dan 573. Pusat Penelitian dan Pengembangan Perikanan. Badan Penelitian dan Pengembangan Kelautan dan Perikanan. Kementerian Kelautan dan Perikanan. $69 \mathrm{p}$.

Triharyuni, S., \& Prisantoso, B.I. (2012). Komposisi jenis dan sebaran ukuran tuna hasil tangkapan longline diperairan samudera Hindia selatan Jawa. Jurnal Saintek Perikanan. 8(1). 52-59.

Trozzi, C., \& Vaccaro, R. (1998). Methodologies for estimating air pollutant emissions from ships. 22nd CIMAC International Conggress on Combustion Engines, Copenhagen. 8 p.

Trozzi, C., \& Vaccaro, R. (2006). Methodologies for estimating air pollutant emissions from ships: a 2006 update. Environment and Transport. 2th In- ternational Scientific Symposium. Reims, France. $9 \mathrm{p}$.

Trozzi, C. (2010). Emission estimate methodology for maritime navigation. US EPA 19th International Emissions Inventory Conference, San Antonio, Texas. $11 \mathrm{p}$

Tyedmers, P. (2001). Energy consumed by north atlantic fisheries. Fisheries impacts on north Atlantic ecosystems: Catch, effort and national/regional data a sets. Fisheries centre, University of British Columbia, Canada. Fisheries centre research reports. 9(3). 12-34

Wibawa, P.A., Birmingham, R.W., \& Woodward, M.D. (2015). Design of sustainable fishing vessels, future challenges for the Indonesian fisheries. $12^{\text {th }}$ International Marine Design Conference 2015. Tokyo. Proceedings (3). 357-367.

Wudianto., Wagiyo, K., \& Wibowo, B. (2003). Sebaran daerah penangkapan ikan tuna di samudera Hindia. J. Lit. Perikan. Ind. 9(7). 19-27.

WWF-Indonesia. (2015). Perikanan cakalang dengan pancing pole and line (huhate). $16 \mathrm{p}$. 
Lampiran 1.

Appendix 1.

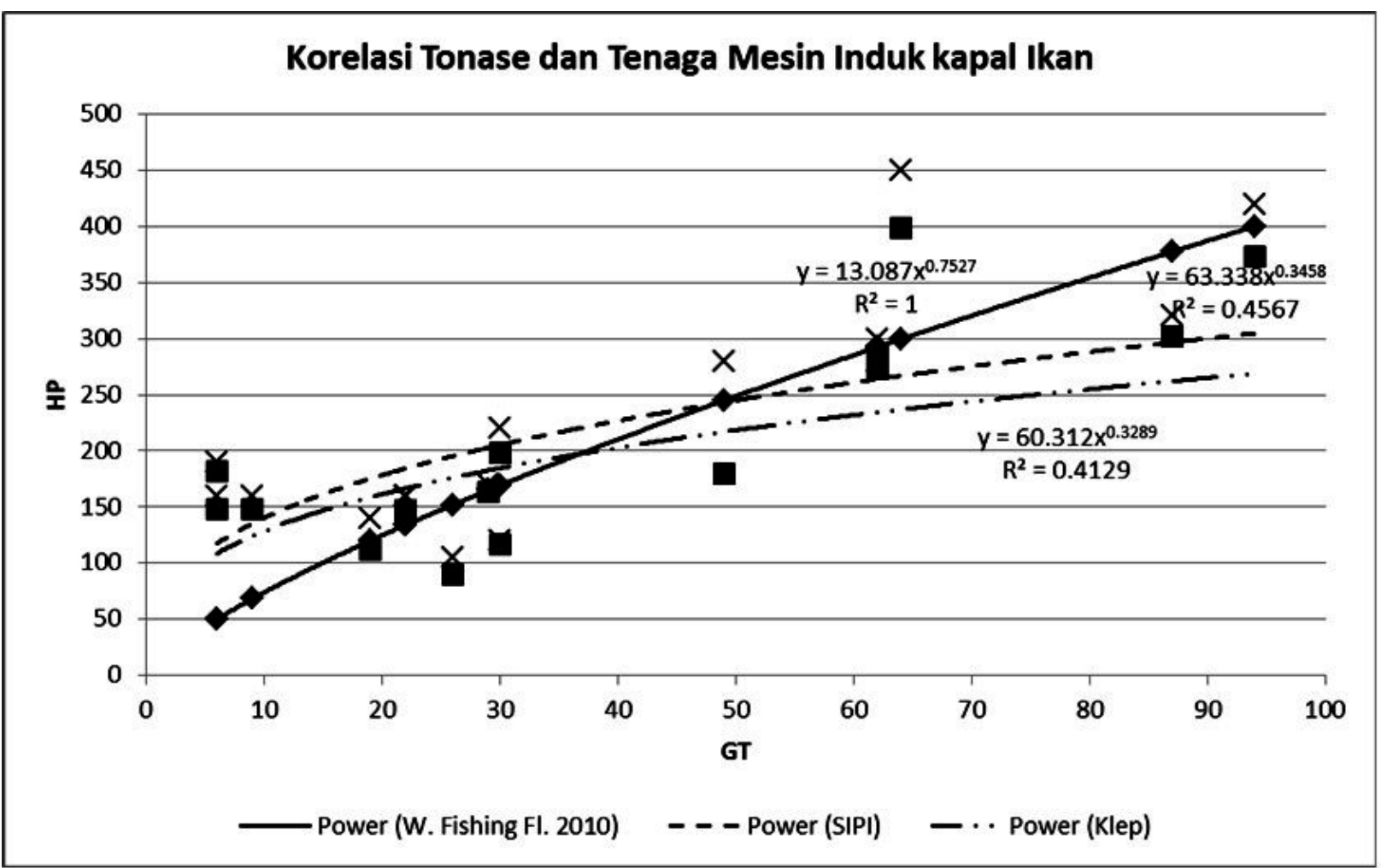

Perbandingan korelasi besar daya mesin induk kapal ikan berdasarkan world fishing fleet 2010 (Trozzi. 2010) serta data SIPI kapal sampel dan model Kleppesto

Correlation of main engine power and tonnage of fishing boat based on world fishing fleet 2010 (Trozzi. 2010), fishing lisence data of sample vessels and Kleppesto model 
Lampiran 2.

Appendix 2.

\begin{tabular}{|c|c|c|c|c|c|c|c|c|c|c|c|c|c|c|c|}
\hline \multirow{4}{*}{ No } & \multirow{4}{*}{ NAMA KAPAL } & \multirow{4}{*}{ GT } & \multirow{4}{*}{ HP } & \multicolumn{12}{|c|}{ MODEL } \\
\hline & & & & \multicolumn{4}{|c|}{ KLEPPESTO } & \multicolumn{4}{|c|}{ DIGERNES } & \multicolumn{4}{|c|}{ HOLLENBACH } \\
\hline & & & & \multicolumn{2}{|c|}{ HP_model/HP_sipi } & \multicolumn{2}{|c|}{ Konstanta BBM (Kg/HP.Jam) } & \multicolumn{2}{|c|}{ HP_model/HP_sipi } & \multicolumn{2}{|c|}{ Konstanta BBM (Kg/HP.Jam) } & \multicolumn{2}{|c|}{ HP_model/HP_sipi } & \multicolumn{2}{|c|}{ Konstanta BBM (Kg/HP.Jam) } \\
\hline & & & & MIN_qpc & MAX_qpc & MIN_qpc & MAX_qpc & MIN_qpc & MAX_qpc & MIN_qpc & MAX_qpc & MIN_qpc & MAX_qpc & MIN_qpc & MAX_qpc \\
\hline $\mathrm{a}$ & $\mathrm{b}$ & c & d & $\mathrm{e}$ & $\mathrm{f}$ & $\mathrm{g}$ & $\mathrm{h}$ & $\mathrm{i}$ & 1 & $\mathrm{k}$ & 1 & $\mathrm{~m}$ & $\mathrm{n}$ & o & $\mathrm{p}$ \\
\hline 1 & L.NB12B & 9 & 160 & 0.93 & 0.70 & 0.227 & 0.171 & 0.51 & 0.39 & 0.144 & 0.109 & 0.36 & 0.27 & 0.076 & 0.058 \\
\hline 2 & L.BIS & 19 & 140 & 0.80 & 0.60 & 0.196 & 0.146 & 0.36 & 0.27 & 0.107 & 0.081 & 0.30 & 0.24 & 0.061 & 0.049 \\
\hline 3 & L.F18 & 22 & 160 & 0.92 & 0.69 & 0.225 & 0.169 & 0.41 & 0.31 & 0.124 & 0.093 & 0.46 & 0.36 & 0.095 & 0.075 \\
\hline 4 & L.Y & 26 & 105 & 0.86 & 0.65 & 0.211 & 0.157 & 0.37 & 0.29 & 0.113 & 0.085 & 0.28 & 0.21 & 0.055 & 0.043 \\
\hline 5 & L.Fri & 6 & 190 & 0.96 & 0.72 & 0.235 & 0.177 & 0.56 & 0.43 & 0.155 & 0.117 & 0.34 & 0.26 & 0.071 & 0.055 \\
\hline 6 & L.F25 & 22 & 160 & 0.92 & 0.69 & \begin{tabular}{ll|}
0.225 \\
\end{tabular} & 0.177 & 0.41 & \begin{tabular}{ll|}
0.31 \\
\end{tabular} & 0.124 & 0.093 & 0.46 & 0.36 & 0.095 & 0.075 \\
\hline 7 & L.NBO9 & 6 & 160 & 0.93 & 0.70 & 0.208 & 0.157 & 0.51 & 0.39 & 0.132 & 0.100 & 0.36 & 0.27 & 0.076 & 0.058 \\
\hline 8 & L.F24 & 22 & 160 & 0.92 & 0.69 & 0.225 & 0.169 & 0.41 & 0.31 & 0.124 & 0.093 & 0.46 & 0.36 & 0.095 & 0.075 \\
\hline 9 & L.F21 & 22 & 160 & 0.92 & 0.69 & 0.208 & 0.157 & 0.41 & 0.31 & 0.114 & 0.086 & 0.46 & 0.36 & 0.095 & 0.075 \\
\hline 10 & L.BS & 30 & 220 & 0.90 & 0.68 & 0.049 & 0.037 & 0.46 & 0.35 & 0.030 & 0.022 & 0.37 & 0.28 & 0.078 & 0.061 \\
\hline 11 & L.F19 & 22 & 160 & 0.92 & 0.69 & 0.050 & 0.038 & 0.41 & 0.31 & 0.027 & 0.021 & 0.46 & 0.36 & 0.095 & 0.075 \\
\hline 12 & L.D3A & 87 & 320 & 0.94 & 0.71 & 0.416 & 0.313 & 0.47 & 0.35 & 0.243 & 0.184 & 0.39 & 0.29 & 0.082 & 0.064 \\
\hline 13 & S.Asp16 & 49 & 280 & 0.64 & 0.49 & 0.035 & 0.027 & 0.30 & 0.23 & 0.020 & 0.015 & 0.23 & 0.18 & 0.048 & 0.037 \\
\hline 14 & K.SM & 29 & 170 & 0.96 & 0.72 & 0.052 & 0.039 & 0.43 & 0.32 & 0.028 & 0.021 & 0.32 & 0.25 & 0.064 & 0.051 \\
\hline 15 & B.D8 & 94 & 420 & 0.89 & 0.67 & 0.049 & 0.037 & 0.49 & 0.37 & 0.031 & 0.023 & 0.39 & 0.30 & 0.083 & 0.065 \\
\hline 16 & B.D16 & 87 & 320 & 0.94 & 0.71 & 0.052 & 0.039 & 0.47 & 0.35 & 0.030 & 0.023 & 0.39 & 0.29 & 0.082 & 0.064 \\
\hline 17 & B.BB & 64 & 450 & 0.89 & 0.67 & 0.049 & 0.037 & 0.52 & 0.39 & 0.033 & 0.025 & 0.37 & 0.28 & 0.079 & 0.061 \\
\hline 18 & AR & 30 & 120 & 0.98 & 0.74 & 0.178 & 0.135 & 0.42 & 0.32 & 0.094 & 0.071 & 0.39 & 0.31 & 0.077 & 0.066 \\
\hline 19 & MB & 62 & 300 & 0.95 & 0.72 & 0.178 & 0.134 & 0.48 & 0.23 & 0.105 & 0.079 & 0.78 & 0.59 & 0.157 & 0.132 \\
\hline 20 & BW & 62 & 280 & 0.98 & 0.74 & 0.183 & 0.138 & 0.53 & 0.40 & 0.114 & 0.086 & 0.46 & 0.35 & 0.093 & 0.078 \\
\hline
\end{tabular}

Hasil estimasi perbandingan daya mesin induk berdasarkan model terhadap daya mesin induk tercatat di SIPI dan konstanta konsumsi BBM mesin induk dan mesin bantu dengan skenario kontanta quasi propulsive minimum dan maksimum

The estimation result of the ratio between the power of main engines derived from the models and the power recorded on fishing lisence certificate and the fuel consumption constant of the main and the auxiliary engines with minimum and maximum quasi propulsive contant scenarios

- (e), (i), (m): Perbandingan daya mesin induk berdasarkan model Kleppesto, Digernes dan Hollenbach dengan skenario quasi propulsive koefisien minimum $(0,564$ - Sampson, 2008) terhadap daya mesin induk tertulis di SIPI.

(e), (i), $(\mathrm{m})$ : The ratios between the power of main engines derived from Kleppesto, Digernes and Hollenbach models and the power written on fishing lisence certificate; using minimum quasi propulsive coefficient (0.564 - Sampson, 2008).

- (f), (j), (n): Perbandingan daya mesin induk berdasarkan model Kleppesto, Digernes dan Hollenbach dengan scenario quasi propulsive koefisien maksimum (0,748 - Sampson, 2008) terhadap daya mesin induk tertulis di SIPI.

(f), (j), (n): The ratios between the power of main engines derived from Kleppesto, Digernes and Hollenbach models and the power written on fishing lisence certificate; using maximum quasi propulsive coefficient (0.748 - Sampson, 2008).

- (g), (k), (o) : Konstanta konsumsi BBM (Kg/HP.jam) mesin induk dan mesin bantu (20\% konsumsi BBM mesin induk) berdasarkan model Kleppesto, Digernes dan Hollenbach dengan skenario quasi propulsive koefisien minimum.

(g), (k), (o): Fuel consumption constant (Kg / HP.jam) of main and auxiliary engines (assumed, $20 \%$ of main engine fuel consumption) based on Kleppesto, Digernes and Hollenbach models using minimum quasi-propulsive coefficient.

- (h), (I), (p): Konstanta konsumsi BBM (Kg/HP.jam) mesin induk dan mesin bantu (20\% konsumsi BBM mesin induk) berdasarkan model Kleppesto, Digernes dan Hollenbach dengan skenario quasi propulsive koefisien maksimum.

(h), (I), (p): Fuel consumption constant (Kg / HP.jam) of main and auxiliary engines (assumed, $20 \%$ of main engine fuel consumption) based on Kleppesto, Digernes and Hollenbach models using maximum quasi propulsive coefficient. 